\title{
Compared to them, we are angels: Parliament, othering and the fight against corruption in Ghana ${ }^{1}$
}

\author{
Kwabena Sarfo Sarfo-Kantankah \\ Senior Lecturer \\ Department of English \\ University of Cape Coast, Cape Coast, Ghana \\ Email: esarfo@ucc.edu.gh \\ Joseph Arko \\ Lecturer \\ Department of English \\ University of Cape Coast, Cape Coast, Ghana \\ Email: jose.arko@gmail.com
}

Submitted: October 31, 2018/ Accepted: June 23, 2019/ Published: December 30, 2019

\begin{abstract}
Due to its supervisory responsibility over the executive and public institutions, including ministries, departments and agencies (MDAs), Ghana's legislature has a mandate to check and fight corruption and make its practice a high risk, low-gain activity. The commitment, urgency and the willingness to fight corruption can be seen not only in creating the legislative framework for addressing corruption, promoting governmental accountability and acting as a check on the executive, but also in how the subject of corruption is broached in parliamentary debates and discussions, an area which relatively lacks scholarly attention. First, using an interpretive content analysis, this paper studies the approaches to the fight against corruption in Ghana by examining the Parliamentary Committee report on the National Anti-Corruption Action Plan (NACAP) and, the debate thereof, in order to uncover the focus of the NACAP. Second, the paper examines Parliamentarians' use of evaluative language in parliamentary debates to enact otherness and how this othering affects the fight against corruption in Ghana. The paper finds that the NACAP suggests a three-pronged approach to the fight against corruption, viz: ethical/educational, multi-stakeholder and legal approaches. However, the implementation of these approaches has been ineffective due to certain Ghanaian cultural practices. Again, the paper finds that as a result of othering between government and opposition MPs, the fight against corruption is only incidental in parliamentary debates, indicating a low parliamentary commitment to the fight against corruption. Thus, the paper suggests that the fight against corruption must be taken away from the corridors of the Parliament of Ghana.
\end{abstract}

Keywords: fight against corruption, parliamentarians, National Anti-Corruption Action Plan, content analysis, evaluative language, othering, Ghanaian parliamentary discourse

\footnotetext{
${ }^{1}$ The paper is a follow-on to Sarfo-Kantankah's (2018) 'Corruption is a big issue: a corpus-assisted study of the discursive construction of corruption in Ghanaian parliamentary discourse', Legon Journal of the Humanities, 29(1), pp.226-258.
} 


\section{Introduction}

Ghanaian Members of parliament (MPs) recognise that there is pervasive corruption in Ghana (Sarfo-Kantankah, 2018). In other words, Ghanaian MPs, to a very large extent, understand and are able to 'communicate the sense in which corruption can be thought of as a danger to' Ghana's socio-political and economic development (Bukovansky, 2006, p. 199). It has been found that Ghanaian MPs discursively construct corruption as a huge systemic social canker that hinders the socio-politico-economic development of Ghana, suggesting 'that stronger measures and more formidable parliamentary commitment are needed to fight corruption' (Sarfo-Kantankah, 2018, p. 226). It is interesting to know that the views of the Ghanaian MPs echo the United Nations Office on Drugs and Crime's (UNODC) (2018, no page) statement that:

Corruption is a complex social, political and economic phenomenon that affects all countries. Corruption undermines democratic institutions, slows economic development and contributes to governmental instability. Corruption attacks the foundation of democratic institutions by distorting electoral processes, perverting the rule of law and creating bureaucratic quagmires whose only reason for existing is the soliciting of bribes. Economic development is stunted because foreign direct investment is discouraged and small businesses within the country often find it impossible to overcome the 'start-up costs' required because of corruption.

With such a strong conviction of the problems of corruption, Ghanaian MPs will be expected to fight corruption in an uncompromising manner. However, it does not appear that MPs are genuinely committed to the fight against corruption. The purpose of this paper is, therefore, to examine and critique, through an interpretive content analysis, the current measures laid down by the Ghanaian Parliament in the National Anti-Corruption Action Plan (NACAP) for the fight against corruption. The study also examines the use of evaluative language to enact otherness in parliamentary debates on corruption in order to investigate how otherness affects MPs' attitudes and commitment to the fight against corruption. Thus, the paper is divided into two complementary parts. The first part examines the current methods for fighting corruption as found in the Parliamentary Committee report on NACAP. The purpose is to demonstrate that there are legislative measures for fighting corruption. The second part, through the principle of evaluation, looks at parliamentary debates in order to explore how parliamentarians broach the fight against corruption and the attitudes they demonstrate. This is necessary because the commitment to implementing the NACAP largely depends on the attitudes of the MPs towards the fight against corruption. The assumption here is that while Parliament has legislative tools to combat corruption, MPs' attitudes indicate low 
Sarfo-Kantankah, K.S. \& Arko, J./Compared to them, we are angels: Parliament, othering and the fight against corruption in Ghana

commitment towards the fight against corruption. Therefore, the paper seeks to respond to the following questions:

1. What are the proposed approaches to the fight against corruption, as contained in the NACAP, and why have those approaches largely failed?

2. How do the MPs enact othering in their debates to circumvent their commitment against the fight against corruption?

In our view, it is not enough to have a legislative framework aimed at fighting corruption. What is needed is a strong political will and commitment to implement such framework. And understanding the commitment of MPs towards fighting corruption requires an assessment of the attitudes portrayed by MPs during their debates. It is in this sense that this paper is significant, especially considering that it engages the concept of othering, through evaluation, to uncover MPs' attitudes towards the fight against corruption. Whereas various studies have suggested ways of fighting corruption, it is unclear how many studies, if any, have done so from the point of view of the attitudes of Ghanaian MPs. We are interested in deploying the concept of othering because it allows us to see what engages MPs' attention in their discourse of the fight against corruption. The concept of othering helps us to observe that, instead of focusing their attention on the fight against corruption, government and opposition MPs engage in the vilification of each other, thereby trivialising the issue of the fight against corruption.

\section{The fight against corruption}

There is no gainsaying that corruption has ravaged most African countries and, therefore, there is the need for strong measures to combat it. Studies have proposed several ways in which countries can successfully fight against corruption. Corruption can be fought through democratic and economic restructuring, strengthening state institutions (Börzela, Stahn and Pamuk, 2010); civic education (Marquette, 2007); enhancing transparency and accountability in state and economic institutions, and social empowerment (Johnston, 1998); and anti-bribery legislation (Cleveland, Favo, Frecka and Owens, 2009). Others include pressure exerted by international bodies such as the European Union and the World Bank (Gadowska, 2010) and strengthening global integrity and ethics (UNODC, 2018a). Also needed are transnational and multilateral cooperation (Bukovansky, 2006), comprehensive and multidisciplinary approach - comprising technical assistance and building institutional capacities (UNODC, 2003, p. 1). This is important because 'corruption is no longer a local matter but a transnational phenomenon that affects all societies 
and economies' (UNODC, 2003, p. 1), and '[s] uccessful international cooperation is required to eradicate the corrosive effects of corruption' (UNODC, 2018b, no page).

Agbele (2011, p. 11) has stated that since the beginning of the fourth Republican and multi-party parliamentary democracy in Ghana, various governments have declared their commitment to fight corruption, yet they have remained mere rhetorical gimmicks. Agbele thinks that legislative reforms are cosmetic with huge implementation gaps, even though he admits that some success has been recorded through 'greater public awareness, media pluralism, some sort of changes in the governance structure' and 'improvement in the legal framework' [sic]. In its press release of $25^{\text {th }}$ January 2017, after the release of the Corruption Perception Index (CPI) 2016, the Ghana Integrity Initiative (2017) recommended among other things that, to fight corruption in Ghana,

the new political and institutional leadership must demonstrate commitment to the fight against corruption by strengthening anti-corruption legislation [emphasis ours] and closing identified gaps; passing outstanding laws such as the Right to Information (RTI) and the Public Officer's Code of Conduct and sanctioning corrupt officials.

According to GAN Integrity $(2016$, p. 1)

Ghanaian anticorruption law is primarily contained in the Criminal Code, which criminalizes active and passive bribery, extortion, willful exploitation of public office, use of public office for private gain and bribery of foreign public officials. The Public Procurement Act, the Financial Administration Act and the Internal Audit Agency Act have been introduced to promote public sector accountability and to combat corruption. The government has a strong anti-corruption legal framework in place but faces challenges of enforcement. Gifts and other gratuities offered to civil servants in the aim of influencing their duties are illegal, nonetheless, facilitation payments are not defined in law.

The statement raises the question of why the anticorruption laws face such implementation challenges. Could it be the result of how Ghanaian law makers see corruption? The view of this paper is that an understanding of MPs' attitudes towards the fight against corruption may unearth some of the underlying challenges associated with the enforcement of anticorruption laws.

A strong Parliament is key to the fight against corruption (Kyei-MensahBonsu, 2013). The Parliament of Ghana is one of the main bodies entrusted with the power to fight corruption. Due to its supervisory responsibility over the executive and public institutions, including ministries, departments and agencies (MDAs), Ghana's legislature has a mandate to check and fight corruption 'and make its practice a high risk, low-gain activity' (Kan-Dapaah, 2015, p. 17). Through its 
Sarfo-Kantankah, K.S. \& Arko, J./Compared to them, we are angels: Parliament, othering and the fight against corruption in Ghana

Public Accounts Committee (PAC), for example, Parliament is mandated to examine the audited accounts of public institutions to ensure accountability. PAC is a creation of the 1992 Constitution of Ghana, with a primary function of examining audited accounts of the government indicating funds granted by Parliament to meet public expenditure and such other accounts laid before the House (Parliamentary Centre, 2009). Article 103 (6) gives PAC the powers, rights and privileges of a High Court in terms of enforcing witness attendance, production of documents, inter alia. In fact, it is only Parliament that is empowered by the 1992 Constitution to give approval or otherwise for the imposition of taxes, determine the waiver or variation of taxes and it is only Parliament that can sanction the withdrawal of funds from the Consolidated Fund of the State. Parliament exercises control over the expenditure of funds (Parliamentary Centre, 2009). Article 187(2) of the 1992 Constitution states that:

The public accounts of Ghana and of all public offices, including the courts, the central and local administrations, of the universities and public institutions of like nature, of any public corporation or other body or organization established by an Act of Parliament shall be audited and reported on by the Auditor-General.

Thus, Parliament has the responsibility to monitor the extent to which governments and public bodies spend funds allocated to them. The foregoing demonstrates the power vested in Parliament for ensuring financial accountability in Ghana. This means that the failure of Parliament to diligently perform these functions has enormous implications for the fight against corruption in Ghana. The implication is that the success, or otherwise, of the fight against corruption largely depends on the level of the commitment of the MPs. In this sense, there is the need to study the attitudes of MPs towards the fight against corruption.

\section{Conceptual framework and review: othering}

Tracing its origins to Hegelian philosophy (Jensen, 2011; Linares, 2016) and drawing on the Lacanian psychoanalytical theory of the ego, Lévi-Struassian ethnography of the other, and Levinasian moral philosophy of 'the face' (Gabriel, 2012), othering acknowledges that the recognition and construction of oneself is achieved through the recognition of the other(Linares, 2016). Othering is considered as the transformation of a difference into otherness for the creation of an in-group and an out-group (Staszak, 2008). Otherness is the result of 'a discursive process by which a dominant in-group ('Us', the Self) constructs one or many dominant outgroups ('Them', Other) by stigmatising a difference - real or imagined - presented as a negation of identity and thus a motive for potential discrimination' (Staszak, 2008 , p. 44). It is a mechanism that is used to distinguish one group from the other. 
As Barter-Godfrey and Taket (2009: 167) put it:

This [othering] is dependent on naming the other to form ideas of group membership; defining otherness to identify some people as an in-group and others as an outgroup; and marking the other so that the out-group members are less favoured when compared to the in-group.

Othering allows for the creation of identities, serving as 'a necessary condition of differentiation in relation', and 'ascribing otherness plays a necessary role in structuring individual identity' (Cooey, 1990, p. 7). Othering is a differentiation strategy for labelling ourselves as more credible than others. Being a 'process of casting a group, an individual or an object into the role of the 'other' and establishing one's own identity through opposition to and, frequently vilification of the other' (Gabriel 2012), othering is a potential ground for conflict between opposed groups. Our view is that otherness leads to social representation of opponents in a polarised manner. Such representation has the potential to drive attention away from the substantive social and political issues.

The concept of othering has been explored from philosophy (e.g. Husserl, 1979); post-colonial theory (where it was originally coined (Said, 1978; Jensen, 2011)), multiculturalism and critical cultural perspective (Said, 1978; Spivak, 1985; see Linares, 2016); feminism (Montoya and Agustin, 2013); including the language classroom (Linares, 2016); health care and health communication (Johnson, Bottorff, Browne, Grewal, Hilton and Clarke, 2004; Barter-Godfrey and Taket, 2009); and media studies and discourse (Breen, Haynes \& Devereux, 2006; Kamenova, 2014) and (critical) discourse analytical perspective (Riggins, 1997). The disciplinary domains where the concept of othering has been employed are numerous. In this study our focus is on political discourse generally and parliamentary discourse specifically.

In political (discourse) studies, the othering theory has been considered, either directly or indirectly, from international politics and nationalism (Göl, 2005; van Houtum and van Naerssen, 2002); British politics (e.g. Charteris-Black, 2006, who explores immigration metaphors in the 2005 British election campaign). Others are found in American politics - e.g. Kinder and Kam (2010), who study the ethnocentric foundations of American opinion; Muller (2008), who studies ethnic nationalism in American politics; and Kaplan, Freedman and Iacoboni (2007), who investigate political attitudes and party affiliation among US presidential candidates; and Leudar, Marsland and Nekvapil (2004), who consider membership categorization in political discourse. In Australian politics, Duck, Hogg, and Terry (1995) have examined political identification and the third person effect in the 1993 Australian federal election. Lirola's (2014) edited eleven-chapter volume, Discourses on immigration in times of economic crisis: a critical perspective, exploring othering/otherness in 
Sarfo-Kantankah, K.S. \& Arko, J./Compared to them, we are angels: Parliament, othering and the fight against corruption in Ghana

Spain, the US, Britain and Central Europe epitomises the concept of othering in recent times.

A number of studies have examined othering in parliamentary discourse. These include: Baker (2015), who studies argumentation, legitimation, and othering in debates on refugees in the Canadian House of Commons; Kirkwood (2017), who looks at the humanisation of refugees in the UK parliamentary debates on the European refugee 'crisis'; and Sosoni (2017), who investigates othering in the Greek parliament. Other studies are: exploration of the description of others in Western parliaments (van Dijk, 1997); parliamentary debates on immigration in Europe (van Dijk, 2000a); ideologies, racism and discourse (van Dijk, 2000b); while van Der Valk (2003) looks at Right-Wing parliamentary discourse on immigration in France. Lazaridis and Tsagkroni (2015) study the securitisation of migration and far right populist othering in Scandinavian countries.

Whereas there have been studies on parliamentary discourse and/or corruption in Africa, hardly do we find studies that have used the concept of othering. For example, Mchakulu (2011) uses issue-specific frame theory for the study of Malawian parliamentary discourse, while Jakaza (2013) employs appraisal theory, pragma-dialectic theory of argumentation and controversy in studying Zimbabwean parliamentary discourse. Mwiinga (2015) employs a critical discourse analytical approach to study Zambian parliamentary discourse; and Peter, Mukuthuria and Muriungi (2016) use the Foucauldian discourse analysis theory to study Kenyan parliamentary debates. Amakali (2018) explores speech acts and their rhetorical purposes in the Namibian parliamentary discourse. In Ghana, Appartaim (2009) and Imbea (2010) study Ghanaian parliamentary discourse from a nativisation perspective; while Jibril and Gyasi (2017) examine English expressions in Ghana's parliament in order to identify Ghanaian English features.

Thus, utilising the concept of othering does not only conceptually add to the various ways in which parliamentary discourse can be studied, but also reveal how Ghanaian MPs' debating strategies undermine the fight against corruption in Ghana. Our assumption here is that an engagement in otherness in parliamentary discourse is fundamentally a blame game, leading to a relegation of the commitment to the fight against corruption. In other words, by accusing each other as being corrupt, MPs divert attention from the sense of common purpose needed to tackle corruption. In order to reveal the othering features of Ghanaian parliamentary debates on corruption, this study deploys an evaluation analytical approach (cf. Thompson and Hunston, 1999). 


\section{Methodology}

\section{Data}

Two main datasets are used for this study. The first is the report of the Committee on Constitutional, Legal and Parliamentary Affairs on the National Anti-Corruption Action Plan (2012-2021). In the legislative process, before a bill is passed into law, it passes through five stages, including: first reading, when the bill is presented to parliament for the first time; committee stage, where the relevant committee scrutinises the contents of the bill and submits a report to Parliament for debate at the second reading stage, where Parliament debates the principles of the bill and the report submitted by the relevant committee (Armah, Sarfo-Kantankah, Bauer \& Mensah, 2018). Thus, the first set of data comprises the Committee report on the NACAP and the subsequent debate on the report. The second set of data is made up of Hansards of debates relating to corruption.

\section{Analytical lenses}

The study employs two analytical approaches: interpretive content analysis and evaluation. While the former is used to assess the existing approaches to the fight against corruption as put forward in the NACAP, the latter is used to examine how othering is deployed by MPs in their parliamentary debates. Content analysis is the analysis of the content of spoken/written communication, including political speeches, through which the conscious and unconscious beliefs, attitudes, values, and ideas can often be revealed (Fraenkel, Wallen \& Hyun, 2012). It is 'a research technique for making replicable and valid inferences from texts (or other meaningful matter) to the contexts of their use [sic]' (Krippendorff, 2004, p. 18), providing a systematic and objective means for making inferences from data (Downe-Wambolt, 1992). A useful method for examining trends and patterns in documents (Stemler, 2001), content analysis helps to organize and elicit meaning from the data collected and to draw realistic conclusions from it (Bengtsson, 2016). As noted by Berelson (1952, cited in Weber, 1990, p. 9), content analysis helps to:

i. identify the intentions and other characteristics of the communicator;

ii. determine the psychological state of persons or groups;

iii. detect the existence of propaganda;

iv. describe attitudinal and behavioural responses to communications; 
Sarfo-Kantankah, K.S. \& Arko, J./Compared to them, we are angels: Parliament, othering and the fight against corruption in Ghana

v. reflect cultural patterns of groups, institutions, or societies;

vi. reveal the focus of individual, group, institutional, or societal attention;

vii. describe trends in communication.

Specifically, the current paper does an interpretive content analysis (Bengtsson, 2016), where it explores the underlying meaning and implications of the NACAP document and MPs' debates around corruption. Thus, the content analysis enables us to discover and describe the focus of the NACAP and MPs' debates on the fight against corruption.

Evaluation refers to statements of value, an assessment of something as either good (that is, desirable) or bad (that is, undesirable) (Fairclough 2003: 172; van Leeuwen 2008: 109-110). According to Thompson and Hunston (1999: 5):

evaluation is the broad cover term for the expression of the speaker or writer's attitude or stance towards, viewpoint on, or feelings about the entities or propositions that he or she is talking about. That attitude may relate to certainty or obligation or desirability or any of a number of other sets of values.

It means that evaluation covers some aspects of modality such as certainty and desirability, as well as the use of evaluative adjectives and adverbs.

Evaluation can be linguistically (grammatically, lexically and textually) and conceptually constructed or recognised (Thompson and Hunston 1999: 13). Grammatically, evaluation is most obviously realised through relational processes (Fairclough 2003: 172), in the form ' $\mathrm{X}$ is [seen by the writer as] $\mathrm{Y}$ ' (Thompson and Hunston 1999: 4). It can also be realised lexically through adjectives, adverbs, verbs and nouns.

Conceptually, evaluation can be realised by 'identifying signals of comparison, subjectivity, and social value’ (Thompson \& Hunston, 1999, pp. 13-14). The most obvious expression of subjectivity is the use of the first person pronoun (I, we). According to Hunston (1985; 1989; cited in Thompson \& Hunston, 1999, p. 14) value-laden evaluation can be realised by considering 'what is good' and 'what is bad' from the point of view of goal-achievement: what is good 'helps to achieve a goal' while what is bad 'prevents or hinders the achievement of a goal'. This, in Martin and White's (2005, pp. 42-43) 'appraisal' terms, is 'judgement', that is, attitudes towards behaviour, which we admire/praise or criticise/condemn (see Sarfo, 2016, p. 83-85). Thus, by employing an evaluative language analysis, we are able to identify how government and opposition MPs each cast themselves into the role of the 'other' and establishing their own identities through opposition to and, frequently vilification of the other (Gabriel, 2012). 


\section{Analysis and discussion}

The analysis and discussion section is divided into two parts. The first part examines the content of the Parliamentary Committee report on the NACAP to bring to bear the various approaches engaged in for the fight against corruption. The second part, through the concept of evaluation, examines parliamentary debates in order to unearth the issue of othering among Ghanaian parliamentarians. The two parts are complementary: while the first part, which lays the background for the second, shows that there are legislative measures for the fight against corruption, the second part suggests that Ghanaian MPs' attitudes betray the nature of their commitment to the fight against corruption.

\section{The fight against corruption in Ghana: the NACAP way}

The most comprehensive expression of the fight against corruption can be found in the National Anti-Corruption Action Plan (NACAP) 2012-2021 and the Report of the Committee on Constitutional, Legal and Parliamentary Affairs on the NACAP. The NACAP and the Committee cite some of the previous measures and policies employed in the fight against corruption as 'moralising crusades', 'public execution of persons', 'passage of draconian decrees', 'confiscation of properties' 'passage of several anti-corruption laws', 'financial management reforms', among others. Corruption was mostly criminalised in order to fight it, especially through the Criminal Code (GAN Integrity 2016, p. 1), with some effort put on moral and value-based crusades. As noted by GAN Integrity $(2016$, p. 1) the Ghanaian 'government has a strong anti-corruption legal framework in place but faces challenges of enforcement'. Several anti-corruption legal frameworks have been put in place. These include the Criminal Offences Act, 1960 (Act 29); the Criminal and Other Offences (Procedure) Act, 1960 (Act 30); and the Criminal Procedure (Amendment) Act, 1965 (Act 261) among recent ones such as the Whistle Blowers Act; the Public Procurement Act; Financial Administrative Act; Article 286 (1) of the 1992 Constitution; and the Public Office Holders (Declaration of Assets and Disqualification) Act, 1998 (Act 550). However, all these have faced implementation challenges and have failed in the fight against corruption. In the view of the NACAP (and the Committee), these policies and measures have failed to fight corruption as expected, and corruption is still endemic in the country (SarfoKantankah, 2018).

The foregoing indicates that, in the fight against corruption, Ghana has struggled to build a culture of rule of law in the midst of building both a liberal and a socialist economy. A free-market driven economy is likely to breed corruption if 
the rule of law is dysfunctional, for 'institutional reforms by themselves do not fare as well where corruption problems are worst' (Johnston, 1998, p. 86). It has been argued that one reason for the failure of anti-corruption approaches is 'the external imposition of contingent standards on societies that are not fully participating in those standards' (Bukovansky, 2006, p. 184). Those standards usually conflict with traditional value systems of those societies, for ' $[\mathrm{w}]$ hat is corrupt in one country may not be corrupt in another' (Casas-Zamora, Walecki and Carlson, n.d). In Ghana, the inability to enforce laws that criminalise corruption may be culturally induced, for " $\mathrm{t}]$ he mobilization of law reflects not only class differences but different norms and values as well' (Silbey, 1989, p. 14). For example, the Ghanaian social structure respects familial and social ties, status, class and organisational positions, which have been said to influence law enforcement. Silbey (1989, pp. 13-14): has argued that:

The legal system reflects and reproduces the encompassing social structure [sic]. Law is costly, and the costs are distributed differently according to social class, status, and organizational positions. Whether in the eighteenth or twentieth century, rates of grievance and litigation reproduce patterns of class, ethnic, and gender stratification. There are differential barriers not only to invoking law but also to complying with law.... Although the uses of law may be situationally structured, the responses and behaviors of legal actors cumulate, with the result that they come to reflect a wider array of social forces than the facts of specific incidents. For example, the ways in which law is mobilized and made available by the police is shaped by the community beyond the enforcement agents.

This implies that the law may be a respecter of person(s), where the political and social elites may get away with corrupt practices. For example, in Ghana, appointment to political and public offices has mostly hinged on nepotism and cronyism (popularly known in Ghana as 'whom you know'), 'political affiliation and patronage', rather than 'meritocracy' (Banaseh, 2017, p. 58). The implication is that the political will to arrest and prosecute corrupt officials may be hindered by the social positions of those officials. The foregoing suggests that Ghana's 'integrity system' is questionable and reform is needed (Eigen, 1998, n.p).

The NACAP states that it utilises a three-pronged approach to the fight against corruption - prevention, education, and investigation and enforcement. However, this paper interprets the NACAP approach in three different broad senses. In view of the failure of the old means of fighting corruption, the NACAP aims 'to contextualize and mobilize efforts and resources of stakeholders, including Government, individuals, civil society, private sector and the media, to prevent and fight corruption through the promotion of high ethics and integrity and the vigorous enforcement of applicable laws' (n.p.). NACAP's mission implies a three-pronged 
Sarfo-Kantankah, K.S. \& Arko, J./Legon Journal of the Humanities Vol. 30.2 (2019)

approach to fighting corruption: ethical/educational, multi-stakeholder and legal approaches.

The ethical approach proposes a value-based system, involving the passage of a comprehensive code of conduct and rules of ethics to govern our actions and inactions and create a value based society. The assumption is that morality in Ghana has declined. The proposal appeals to the moral integrity of public officials and the general public, and it survives on personal conscience about right and wrong. The approach hints at the cultural interpretations of what constitutes corruption. It calls for civic education, since '[i]t is difficult if not impossible to sustain anticorruption reforms without ... effective public/civic education' (Gyimah-Boadi, 2004, p.3). It means educating the people about what is right and wrong and what constitutes corruption, which ties in with the sensitisation and education of the public about the dangers of corruption. This will entail normative measures based on Ghanaian cultural values, for '[1] aw is a culturally variable phenomenon, and each society, culture, and subculture makes of it something that belongs to that grouping' (Silbey, 1989, p. 17). As noted by Sparling (2016, p. 172) '[b]oth mores and laws are essential for the minimization of corruption'. Considering that the failed laws included embarking on moralising crusades with the help of religious and community leaders, one wonders how the new ethical approach contained in the NACAP can help fight corruption comprehensively. Perhaps, the multilateral approach comes to the rescue.

The multi-stakeholder/multilateral approach sees the fight against corruption as a collective responsibility, as one MP puts it, 'we [are] insisting on ownership of this process [of fighting corruption] by Ghanaians this time' (Hansard 22 July 2015/ Col.3347). It advocates the involvement of all stakeholders through sensitisation of the general public on corruption; empowering the citizenry to report corruption; building public capacity to condemn, rather than celebrating and admiring 'those who flaunt their ill-gotten wealth' (Banaseh, 2017, p. 58). It also involves engaging the media and organisations; nationwide awareness creation and sensitization on corruption; and public education to improve understanding of issues relating to corruption. The multilateral approach is significant because, as the Committee notes, [t]he fight against corruption will bear little fruit without raising the awareness of public officials and the general public to the dangers of corruption and the duty of every citizen to combat corruption. Involving the public in the fight against corruption is important, for corruption renders the people less public-spirited (Sparling, 2016, p. 160), which in turn erodes public trust and threatens democracy. Engaging the citizenry is publicity, for 'as secrecy is a defining component of corrupt practices, publicity is a defining component of anti-corruption campaigns' 
(Bukovansky, 2006, p. 186). Publicity is a means by which civil society groups 'can exert pressure on government and the private sector for greater transparency and accountability' (Eigen, 1998, n.p). A key tool for such publicity is the enactment and implementation of the right to information $\mathrm{law}^{2}$, which is more likely to empower citizens to partake in the fight against corruption. Encouraging publicity is to engage the media and the general public in the democratic process, which strengthens the democratic credentials of the country and the corruption fight. Media freedom and democracy are considered to be key in the fight against corruption (Bhattacharyya and Hodler, 2015). Democracy involves social empowerment, which is essential in the battle against corruption. As noted by Johnston (1998, p. 85):

While institutional reforms enhancing transparency and accountability in the state and economic institutions are indispensable parts of any anti-corruption strategy, they also need a long-term social foundation, particularly where corruption is systemic. Social empowerment - expanding and protecting the range of political and economic resources, and alternatives, open to ordinary citizens - is one way to address the task. Social empowerment entails strengthening civil society in order to enhance its political and economic vitality, providing more orderly paths of access and rules of interaction between state and society, and balancing economic and political opportunities.

While the publicity method appears plausible, we daresay that if the legal approach does not play its role of arresting and prosecuting corrupt officials, the exposure of corruption alone will not be enough, and vice-versa. For instance, what is the point and to what end, if exposed corrupt official go scot-free? As Manasseh Azure Awuni ${ }^{3}$ argues, what is important for journalists is knowing that the issues of corruption they expose are dealt with and that Ghana will not get anywhere in the fight against corruption when those exposed go without punishment. This is the more reason the legal approach is crucial in fighting corruption.

The legal approach appears to be the most common (and important) among the means to combat corruption, as suggested by the MPs. It encompasses strengthening the country's Anti-Corruption Legislative Framework through the passage of several Anti-Corruption Laws, conduct[ing] effective investigations and prosecution of corrupt conduct, the right of access to information law, resourcing and making use of anti-corruption bodies such as Commission on Human Rights and Administrative Justice (CHRAJ), the Ghana Police Service, Economic and

\footnotetext{
${ }^{2}$ The Right to Information Bill, which was passed into law in March 2019, gives substance to Article 21 (1) (f) of the Constitution which states that 'All persons shall have the right to information subject to such qualifications and laws as are necessary in a democratic society'. The preparation of the bill started in 1999, but it had not been passed since 2010 when it was presented to Parliament. The bill seeks to enable the citizenry to ensure accountable governance by holding governments accountable.

${ }^{3}$ Manasseh Azure Awuni is a Ghanaian investigative journalist with the Multimedia Group Ltd. He is an anticorruption crusader. He won the 2018 West African Journalist of the year award. He made this statement when he delivered a speech after winning the award on October 14, 2018, Accra, Ghana. See the Ghana News Agency's report at: http:/www.ghananewsagency.org/social/ manasseh-azure-wins-2018-west-african-journalist-of-the-year-140040
} 
Organised Crime Office, Audit Service. Even though MPs recognise the need to resource these anti-corruption institutions to enable them to fight against corruption, the bodies lack funds and resources to perform their functions. For instance, a former commissioner of CHRAG, Justice Emile Short, has bemoaned the lack of funds and resources to enable anti-corruption institutions to operate effectively (Banaseh, 2017). There is evidence to show that governments and MPs have often stated the need to resource these institutions. In the 2014 budget statement read to Parliament, the then finance minister stated that, as part of the government's transparency and anti-corruption initiatives:

additional budget provisions have been made to strengthen anti-corruption agencies, notably, CHRAJ. Also, as directed by H. E. the President, a percentage of proceeds of corruption when recovered, will be paid to anti-corruption agencies instrumental in exposing such acts, and this will further strengthen their resource base.

Government's Financial Policy, 2014 (para. 1026)

The expression of commitment to resource anti-corruption bodies to fight corruption abounds in the data. Thus, lack of resources for the anti-corruption institutions indicates a disconnect between political rhetoric and practical action. As one MP notes, '[w] can only succeed in the fight against corruption if we move from rhetoric to action' (Hansard 26 November 2013/Col.1403). The former CHRAJ boss, Emile Short, partly attributes Ghana's inability to fight corruption to the kind of multiparty democracy practised in Ghana, where political parties and politicians are funded by corrupt people who use all manner of means to recoup what they have lost. This means that the state's inability to sponsor political parties is a recipe for corruption. However, the MPs appear to be silent on the nature of our multiparty democracy as a contributory factor for our failure to fight corruption.

In the discussion of the NACAP on the floor of Parliament, MPs unanimously agree that the NACAP is an important step towards the fight against corruption; MPs seem to hold a common sense of purpose in the corruption fight. However, when it comes to debates on the issue of corruption and the fight against it, they appear to lack the single-mindedness needed to tackle corruption, as they engage in a blame game that leads to othering. Thus, we argue that the difficulty in fighting corruption partly emanates from what is called othering, a means by which MPs relegate the fight against corruption to the background and engage in a blame game, as discussed in the next section. 


\section{Othering and the fight against corruption}

Othering is one of the commonest ways of constructing corruption in parliamentary debates. Often in the parliamentary debates, government and opposition MPs label each other as corrupt. Corruption is largely dependent upon the control of state resources and it is the ruling party/government which controls the resources. Thus, corruption seems to turn when the tables turn, that is, when governments lose power and new ones take over. For example, in a reaction to an NPP MP's allegations of corruption against the NDC government, an NDC MP cautions 'political office holders to be measured in terms of the words they use against one another. This is because the table only just goes round, and we find yourself [ourselves] on the other side' (Hansard 26 November 2013/Col.1385).

The extracts in Table 4 below, which come from debates on the floor of Parliament, illustrate othering by MPs. Instances of othering abound in the debates, but for want of space, we are considering only these. Extracts 1A and 2A come from opposition MPs, while 1B and 2B are from position/government MPs. Extract 1B is a response to $1 \mathrm{~A}$, whereas $2 \mathrm{~B}$ is to $2 \mathrm{~A}$. In Example $1 \mathrm{~A}, \mathrm{Mr}$ Iddrisu accuses the President of paying lip service to the fight against corruption, and indirectly indicts the President for superintending over corruption, as in, the office of accountability operates in darkness. Mr Iddrisu achieves his purpose through the use of evaluative language, as in:

i. I think that the President's declaration...

ii. But in my view it is not to be achieved with the self-serving Office of Accountability...

iii. I think that if we are serious and the President means business... he should come with a legislation.

The expressions I think and in my view indicate Mr Iddrisu's subjective evaluation of the President's commitment to the fight against corruption. He sees the President's establishment of the Office of Accountability as self-serving, a negative evaluative adjective suggesting a 'negation of identity' of the President (Staszak, 2008, p. 44). That the Office operates in darkness demonstrates $\mathrm{Mr}$ Iddrisu's impression that the Office is corrupt and that the President 
Table 4: Extract samples illustrating othering by MPS

\section{Extract 1A \\ Mr. Haruna Iddrisu (NDC, opposition) 8 February 2006/Col.566}

Mr. Speaker, I think that the President's declaration of 'zero tolerance' was significant for our national fight against the canker of corruption. But in my view it is not to be achieved with the selfserving Office of Accountability when we do not know the cases they deal with, which persons are affected, what issues are involved. Parliament is not informed and, the Public is not informed. Mr. Speaker, what corruption hates is exposure; therefore it loves darkness. The Office of Accountability operates in darkness. Nobody seems to know what that office does. I think that if we are serious and the President means business in fighting corruption, he should come with legislation so that - [Interruption.]

\section{Extract 2A}

Mr I. K. Asiamah (NPP, opposition) 26 November 2013/Col.1385

Mr Speaker, the report further states that there has been a financial loss to the State to the tune of about $\mathrm{GH} \notin 150$ million, that is about $\phi 9.5$ trillion [old cedis]. Mr Speaker, it goes on to state that there is a further ration debt to the tune of GHф259 million. So, in total, we have about $\mathrm{GH} \phi 1.2$ billion, that is about $\mathrm{GH} \phi 12$ trillion [old cedis] lost to the State. Mr Speaker, this is the highest level of corruption that we should never entertain. Mr Speaker, they create, loot and share.

\section{Extract 1B \\ Mr. Maxwell Kofi Jumah (NPP, position) 9 February 2006/Col.665}

... We have seen Ministers in other governments, in other regimes in this country. We have seen them. I counted the number of cars in a former Ministry of Education and there were six official cars - six - [Interruption] — do not even talk about it. Mr. Speaker, and these people have the nerve to talk about corruption.

... Mr. Speaker, the Auditor-General's Report that is right here in this House, let us take one year, any year, let us probably toss a coin and pick any year and look at it, and we would not need to talk about corruption again because compared to them we are all angels in the New Patriotic Party ( NPP). All of us, everybody in the NPP is an angel, compared to them. Of course, we need to do more because this is a Government that aspires to do even better, even though it is doing good.

\section{Extract 2B}

Mr Murtala M. Ibrahim (NDC, position) 26 November 2013/Col.1405

... Now, if there is any commitment that any Government has ever made towards fighting corruption, between what the Government has done and a Government that says that it would not prosecute corrupt people because I risk collapsing my Government. Between a Government which has taken the steps and said investigate, prosecute and the President who says he will not investigate alleged corruption in his Government because if he did that he risked collapsing his Government, she stands there questioning the commitment of that Government, which is fighting corruption. Is that the kind of nation we would want to build? I think that if there is any commitment that has ever been made, it is about this Government. 
has no commitment towards the fight against corruption. In this sense, $\mathrm{Mr}$ Iddrisu's subjective focus is more on the President than on the issue of the fight against corruption. Such a position usually elicits counter-attacks. Thus, in response to the accusation of corruption against the President and his government, $\mathrm{Mr}$ Jumah (1B) counter-accuses the former NDC administration of massive corruption exemplified in the number of cars that were in the former Ministry of Education, questioning the moral authority of the members of the previous government to talk about corruption. He claims the NPP are comparatively better, saying compared to them we are all angels. This is a comparison of the NPP's and NDC's positions on the fight against corruption, leading to a value evaluation of the two (Thompson \& Hunston, 1999). Again, consider Mr Jumah's subjective evaluation of the performance of the previous NDC administration, as seen in such forms as we, $I$, these people and all of us in i-vi.

i. We have seen Ministers in other governments, in other regimes in this country.

ii. We have seen them.

iii. I counted the number of cars in a former Ministry of Education...

iv. ... these people have the nerve to talk about corruption.

v. $\quad .$. we are all angels in the New Patriotic Party ( NPP).

vi. All of us, everybody in the NPP is an angel, compared to them.

There is a construction of $u s$ and them, an in-group (we) and an out-group (these people) (Staszak, 2008), a creation of otherness (Barter-Godfrey \& Taket, 2009).

Similarly, in Extract 2A, Mr Asiamah accuses the NDC administration of being corrupt, that is, they create, loot and share, a value-laden evaluation (Thompson \& Hunston, 1999) of the governance style of the NDC. In 2B, Mr Ibrahim defends his government as having shown a better commitment to fighting corruption and condemns the former President (NPP administration) for refusing to investigate and prosecute corrupt officials in order not to collapse his government. Consider Mr Ibrahim's indirect comparison between the previous NPP government and the current NDC government:

i. $\quad \ldots$ a Government which has taken the steps and said investigate, prosecute (i.e. the Government, which is fighting corruption); and

ii. ... the President who says he will not investigate alleged corruption 
in his Government because if he did that he risked collapsing his Government...

Mr Ibrahim evaluatively portrays the NDC and its government as desirable, with a better commitment towards the fight against corruption, and the NPP and its previous government as undesirable, lacking the needed commitment (Fairclough, 2003; van Leeuwen, 2008). The extracts are, therefore, a 'judgement' (Martin \& White, 2005, pp. 42-43) of the attitudes of the two political groups towards the fight against corruption in Ghana. Each group sees the other group as not having the requisite commitment to fighting corruption.

These extracts can be said to be instances of othering, ways of distinguishing 'us', the honest; from 'them', the corrupt; 'the normal from the deviant' (BarterGodfrey and Taket, 2009, p. 166), attributing attitudes, opinions and views to opponents (Gabriel, 2012). Corruption is both a moral and a legal issue. As Sparling (2016, pp. 157, 161) notes, '[c]orruption discourse is political morality'. Thus, to call someone corrupt is to question and attack one's moral integrity and love for one's country, a diminution of one's virtue. It is a construction of a virtuous self as against a bad other, which is an identity formation through positive and negative othering. It is not surprising, therefore, that there are accusations and counteraccusations between position and opposition MPs.

If corruption 'entails an alteration of people's primary desires such that they no longer serve to unite disparate individuals' (Sparling, 2016, p. 166), the discourse of corruption in parliament divides parliamentarians in a more starkly uncompromising way. This is because 'a primary concern of MPs [during debates] is to reinforce their own credibility (Ilie, 2003, p. 81), while they raise doubts about the trustworthiness of their opponents. As portrayed in the extracts above, the discussion of corruption in parliament suggests a trial of the political values and norms of political opponents. For example, they create, loot and share damages the reputation of the NDC government. MPs create a sense of 'saints' and 'demons' through ethical appeals that result in emotional outbursts from MPs whose honesty is questioned. For instance, Mr Osei-Prempeh (NPP - Nsuta-Kwamang/Beposo) questions the credibility of the President in fighting corruption when he says: The President comes and he talks against corruption, yet he appoints people who have been tainted with corruption into his Government, into top Cabinet positions ... And you say that you are fighting corruption? (Hansard: 2 Mar 2010/Col.14471448). The implication is that there is no unity of purpose required from MPs in fighting corruption.

The stark division in the face of discussions of the issues of corruption 
is a relegation of the fight against corruption. By framing corruption through othering, rather than the substantive problem of corruption, brings into question parliamentarians' commitment towards the fight against corruption. As an MP admonishes his fellow MPs: 'when the issue of corruption crops up, we [MPs] should all work together as a unit to ensure that boldly and decisively, we tackle [it]' (Hansard 2 March 2011/Col. 1928). Othering reduces the fight against corruption to a political blame game, for '[p]ublicly calling a person or government corrupt is a political act' (Bukovansky, 2006, p. 185). It portrays the MPs as lacking the 'political will', that is, 'the demonstrated credible intent of political actors ... to attack perceived causes or effects of corruption at a systemic level' (Kpundeh, 1998, n.p).

It must be noted, however, that personality attacks are not necessarily bad in politics and political campaigns. The attacks and counter-attacks are a feature of negative campaign. According to Mayer (1996), negative campaigning and negative portrayals of political opponents are important for measuring the quality, trustworthiness and credibility of candidates who put themselves up for elections. All parliamentary (and political) debates can be justifiably considered as political campaigns, for MPs always have in mind the next election, when they make statements about the weaknesses and strengths of incumbent (or past) governments to either discredit or credit them. Every political statement has the potential to influence future elections. As stated by one NPP MP:

... in 2008, all of us, we are going to present ourselves to the electorate who voted us in here. ... This is the time to separate the weed from the chaff; this is the time to ask ourselves, are we doing this on principle? Even if I am going to be voted against, I am going to vote for this because it is the right thing and not politics.

Hansard 9 February 2006/Col.664

Calling opponent MPs corrupt and lacking the ability to fight corruption is to expose their weakness and dishonesty and their inability to govern the country, which implies that the electorate must consider voting them out of government. The ability to expose the weaknesses of political opponents offers the criticiser the opportunity to propose an alternative, for without knowing the weaknesses of the incumbent and the deficiencies of the current ways of fighting corruption will make it difficult for the opposition to offer alternative proposals. This is necessary because, from serious domains such as academia/academic research writings, through popular and everyday debates to politics, arguments and campaigns are organised in ways that first examine the weakness, defects and shortcomings of present research findings, arguments or policies before proposing new ones or solutions (Mayer, 1996). And 'a candidate who is challenging an incumbent should 
be required to show the weaknesses and shortcomings of his opponent, and then to indicate how and why he should do better' (Mayer, 1996, p. 454). This accounts for the opposition MPs' incessant portrayal of incumbent governments as corrupt. On the other hand, '[a]n incumbent should defend his own record, and then (since that record is unlikely to be entirely without blemish) should be able to point out the ways in which the challenger would be deficient' (Mayer, 1996, p. 454). It is not surprising, therefore, that there are accusations and counter-accusations between government and opposition MPs. The argument we are making here is that even though the personality attacks and counter-attacks appear to drive attention away from the substantive issue of corruption, they are not necessarily detrimental. What is important is for us to consider whether the accusations and counter-accusations are based on truth and are relevant and provide a guide to understanding the personality and character of those accused of corruption.

\section{Conclusion}

The purpose of this paper has been to analyse, through a content analytical approach, the ways of fighting corruption in Ghana as proposed by the National Anti-Corruption Action Plan (NACAP), including MPs' debates and Parliamentary Committee reports on the NACAP. Through the principle of evaluation, the paper also explored otherness in parliamentary debates on corruption in order to observe how otherness affected MPs' attitudes and commitment towards the fight against corruption in Ghana. The aim was to assess the intentions, the psychological, attitudinal and behavioural responses of the MPs towards the fight against corruption.

The paper notes that the NACAP proposes a three-pronged approach to the fight against corruption, namely:

(i) ethical/educational approach, that is, the creation of a value-based society with strong moral principles that promote high ethics and integrity, and the sensitisation of the people on the dangers of corruption;

(ii) multi-stakeholder approach, involving stakeholders such as the media, civil society and the general public to expose corruption; and

(iii) legal approach, which involves the strengthening of anticorruption legislation, resourcing anticorruption agencies and the effective implementation and enforcement of anticorruption laws.

The paper argues that the failure of these approaches in the fight against 
corruption results from Ghanaian cultural and social systems, where familial relationships, social ties, class, status and organisational positions have huge negative influences on the rule of law. In other words, Ghana has failed to build a culture of the rule of law. In the view of this paper, the main approach that can successfully combat corruption is commitment to the implementation and enforcement of, particularly, anti-corruption laws and, generally, the rule of law.

The study has shown that one arena where othering (and otherness) manifests itself is parliament, where ideological tensions revolve around the social representations of the majority (government MPs) and the minority (opposition) MPs, who 'are positioned in the place of a dichotomy that polarises [their] collective identity in relation to what is perceived as good or bad' (Linares, 2016, p. 131). Othering allows for the objectification, differentiation and stereotyping of government and opposition MPs, ideologically constructing themselves as a binary us and them (van Dijk, 2011, p. 396). Through the concept of othering, Ghanaian MPs label each other as corrupt, making the discussion of the fight against corruption merely incidental to their debates and discussions. In other words, Ghanaian MPs' debating strategies hinder the fight against corruption in Ghana. Instead of collectively agreeing that they have to fight corruption together and work towards that, the MPs are preoccupied with indicating which of them (the Majority and the Minority) are more corrupt than the other. Thus, the MPs do not necessarily deny that they are corrupt; they disagree on who is more or less corrupt, making them lose focus on the substantive issue of the fight against corruption. This brings into question Ghanaian parliamentarians' commitment towards the fight against corruption. To this end, we do agree with the current Majority Leader and Minister for Parliamentary Affairs, Mr Osei Kyei-Mensah-Bonsu, that the fight against corruption must be taken away from the corridors of Parliament ${ }^{4}$.

While it is well known that legislation and the law (Lawal, 2007; Cleveland, Favo, Frecka and Owens, 2009), strengthening state institutions (Börzela, Stahn and Pamuk, 2010), among others, are useful for fighting corruption, this paper has demonstrated that the attitudes of those who implement anti-corruption laws are essential for the fight against corruption. We argue that one of the challenges facing the enforcement of Ghana's strong anti-corruption legal framework (GAN Integrity, 2016) emanates from lack of commitment on the part of Ghanaian MPs as a result of their othering orientations. The implication is that studies on corruption and the fight against it must turn attention to the attitudes and the commitment of those who implement the anticorruption laws.

\footnotetext{
${ }^{4} \mathrm{Mr}$ Kyei-Mensah-Bonsu made this statement in an interview with Nana Aba Anamoah's State of Affairs, current affairs show on
} GHOne TV. The programme is held at $7 \mathrm{pm}$ every weekday. 


\section{References}

Agbele, F. (2011). Political economy analysis of corruption in Ghana. European Research Centre for Anti-Corruption and State-Building (ERCAS) Working Paper No. 28.

Amakali, J.M.L. (2018). Speech acts and their rhetorical purposes in the Namibian parliamentary discourse, 2015-2016. (PhD Thesis). The University of Namibia.

Armah, E.N.A., Sarfo-Kantankah, K.S., Bauer, G. and Mensah, G. (2018). Report on the first session of seventh parliament 2017. A report conducted by Odekro, a non-profit parliamentary monitoring organisation, and sponsored by STAR-Ghana with funding from UKaid, DANIDA and the European Union.

Baker, J.T.E. (2015). Defending the indefensible? the use of argumentation, legitimation, and othering in debates on refugees in the Canadian House of Commons, 2010-2012.(PhD Thesis). Memorial University of Newfoundland.

Banaseh, M.A. (2017). Ghana losing fight against corruption - Emile Short. Daily Graphic, November 29, p. 58.

Barter-Godfrey, S. \& Taket, A. (2009). Othering, marginalisation and pathways to exclusion in health. In A. Taket, B.R. Crisp, A. Nevill, G. Lamaro, M. Graham \& S. Barter- Godfrey (Eds.), Theorising social exclusion (pp.166172), Routledge, Abingdon, England.

Bengtsson, M. 2016. How to plan and perform a qualitative study using content analysis. NursingPlus Open, 2, 8-14. Retrieved from http://dx.doi. org/10.1016/j.npls.2016.01.001

Bhattacharyya, S. \& Hodler, R. (2015). Media freedom and democracy in the fight against corruption. European Journal of Political Economy, 39, 13-24.

Börzel, T.A., Stahn, A \& Pamuk, Y. (2010). The European Union and the fight against corruption in its near abroad: can it make a difference?, Global Crime, 11(2), 122-144. DOI: 10.1080/17440571003669142

Breen, M.J., Haynes, A. \& Devereux, E. (2006). Fear, framing and foreigners: the othering of immigrants in the Irish print media. International Journal of Critical Psychology, 16, 100-121.

Bukovansky, M. (2006). The hollowness of anti-corruption discourse. Review of International Political Economy, 13(2): 181-209. 
Sarfo-Kantankah, K.S. \& Arko, J./Compared to them, we are angels: Parliament, othering and the fight against corruption in Ghana

Casas-Zamora, K, Walecki, M., \& Carlson, J. (no date). Political Integrity and Corruption - an international perspective. Retrieved from https://ifes.org/ sites/default/files/political_integrity_introduction_english_0.pdf

Charteris-Black, J. (2006). Britain as a container: immigration metaphors in the 2005 election campaign. Discourse \& Society, 17(5), 563-581.

Cleveland, M., Favo, C., Frecka, T., \& Owens, C. (2009). Trends in the international fight against bribery and corruption. Journal of Business Ethics, 90, 199-244. Retrieved from http://www.jstor.org/stable/40665294

Cooey, P.M. (1990). Emptiness, otherness, and identity: a feminist perspective. Journal of Feminist Studies in Religion, 6(2), 7-23.

Downe-Wambolt, B. (1992). Content analysis: method, applications and issues. Health Care for Women International, 13, 313-321.

Duck, J. M., Hogg, M. A., \& Terry, D. J. (1995). Me, us and them: political identification and the third-person effect in the 1993 Australian federal election. European Journal of Social Psychology, 25(2), 195-215.

Eigen, P. (1998). Message from Transparency International. In Corruption and Integrity Improvement Initiatives in Developing Countries. New York: United Nations Development Programme.

Fairclough, N. (2003). Analysing discourse: Textual analysis for social research. London:Routledge.

Fraenkel, J.R., Wallen, N.E. and Hyun, H.H. (2012). How to design and evaluate research in education (8th ed.). New York: McGraw-Hill.

Gadowska, K. (2010) National and international anti-corruption efforts: the case of Poland. Global Crime, 11(2), 178-209. DOI:10.1080/17440571003669191

GAN Integrity. (2016). Ghana Corruption Report. Accessed 26 July 2017, at: http:// www.business-anti-corruption.com/country-profiles/ghana

Ghana Integrity Initiative. 2017. Press Release: The Corruption Perception Index 2016. Retrieved from https://www.tighana.org/assets/Uploads/DOC20170125-WA0000.pdf

Göl, A. (2005). Imagining the Turkish nation through 'othering' Armenians. Nations and Nationalism, 11(1), 121-139.

Gyimah-Boadi E. (2004). New anti-corruption governments: the challenge of delivery - Ghana: a case study. Prepared for the New Anti-Corruption Governments Meeting, Organised by the Government of Kenya, TI-Kenya and the TI Secretariat, Nairobi, October. Retrieved from http://www. 
Sarfo-Kantankah, K.S. \& Arko, J./Legon Journal of the Humanities Vol. 30.2 (2019)

worldbank.org/wbi/governance/ghana/pdf/gha_thechallengeofdelivery_ac asestudy.pdf.

Hunston, S. (2011). Corpus approaches to evaluation: Phraseology and evaluative language. London: Routledge.

Husserl, E. (1969). Formal and transcendental logic. The Hague, NL: Martinus Nijhoff.

Ilie, C. (2003). Discourse and metadiscourse in parliamentary debates. Journal of Language and Politics, 2(1): 71-92.

Jakaza, E. (2013). Appraisal and evaluation in Zimbabwean parliamentary discourse and representation in newspaper article. ( $\mathrm{PhD}$ Thesis). Stellenbosch University.

Jensen, S.Q. (2011). Othering, identity formation and agency. Qualitative Studies, 2(2), 63-78.

Jibril, H.S. \& Gyasi, Y.O. (2017). English expressions in Ghana's parliament. International Journal of English Language and Linguistics Research, 5(3), 49-63.

Johnson, J.L., Bottorff, J.L., Browne, A.J., Grewal, S., Hilton, B.A., \& Clarke, H. (2004). Othering and being othered in the context of health care services. Health Communication, 16(2), 253-271.

Johnston, M. (1998). Fighting systemic corruption: social foundations for institutional reform. The Journal of Development Research, 10(1), 85-104. https://doi.org/10.1080/09578819808426703

Kamenova, D. (2014). Media and othering: how media discourse on migrants reflects and affects society's tolerance. Plitické Vedy, 17(2), 170-184.

Kan-Dapaah, A. (2015). Parliament's role in the fight against corruption. Accra: Institute of Economic Affairs (IEA).

Kaplan, J. T., Freedman, J., \& Iacoboni, M. (2007). Us versus them: political attitudes and party affiliation influence neural response to faces of presidential candidates. Neuropsychologia, 45(1), 55-64.

Kinder, D. R. \& Kam, C. D. (2010). Us against them: ethnocentric foundations of American opinion. University of Chicago Press.

Kirkwood, S. (2017). The humanisation of refugees: a discourse analysis of UK parliamentary debates on the European refugee 'crisis'. Journal of Community \& Applied Social Psychology, 27(2), 115-125. 
Sarfo-Kantankah, K.S. \& Arko, J./Compared to them, we are angels: Parliament, othering and the fight against corruption in Ghana

Kpundeh, S.J. (1998). Political will in fighting corruption. In Corruption and Integrity Improvement Initiatives in Developing Countries. New York: United Nations Development Programme.

Krippendorff, K. (2004). Content analysis: An introduction to its methodology $\left(2^{\text {nd }}\right.$ ed.) Thousand Oaks, California: Sage Publications.

Kyei-Mensah-Bonsu, O. (2013). A strong parliament is key to fighting corruption - Minority Leader. Retrieved from https://www.myjoyonline.com/ politics/2013/November- 13th/a-strong-parliament-is-key-to-fightingcorruption-minority-leader.php

Lawal, G. (2007). Corruption and development in Africa: challenges for political and economic challenge. Humanity \& Social Journal, 2(1): 01-07.

Lazaridis, G. \& Tsagkroni, V. (2015). Securitisation of migration and far right populist othering in Scandinavian countries. In G. Lazaridis \& K. Wadia (Eds.), The Securitisation of Migration in the EU (207-236). London: Palgrave Macmillan.

Leudar, I., Marsland, V. \& Nekvapil, J. (2004). On membership categorization: 'us', 'them' and 'doing violence' in political discourse. Discourse \& Society, 15(2-3), 243-266.

Linares, S.M. (2016). Othering: Towards a critical cultural awareness in the language classroom. HOW, 23(1), 129-146.

Lirola, M. M. (Ed.). (2014). Discourses on immigration in times of economic crisis: a critical perspective. Cambridge Scholars Publishing.

Marquette, H. (2007). Civic education for combating corruption: lessons from Hong Kong and the US for donor-funded programmes in poor countries. Public Administration and Development, 27, 239-249.

Martin, J.R. \& White, P.R.R. (2005). The language of evaluation. Hampshire: Palgrave.

Mayer, W.G. (1996). In defence of negative campaigning. Political Science Quarterly, 111(3): 437-455.

Mchakulu, J.E.J. (2011). Framing political communication in an African context: a comparative analysis of post-election newspaper editorials and parliamentary speeches in Malawi. (PhD Thesis). University of Leicester.

Montoya, C. \& Agustin, L.R. (2013). The othering of domestic violence: the EU and cultural framings of violence against women. Social Politics, 20 (4), 534-557. 
Sarfo-Kantankah, K.S. \& Arko, J./Legon Journal of the Humanities Vol. 30.2 (2019)

Mwiinga, C. (2015). A critical discourse analysis of the parliamentary debate on the lifting of the immunity of the fourth republican president of Zambia in 2013. (MA Thesis). University of Zambia.

Muller, J. Z. (2008). Us and them: the enduring power of ethnic nationalism. Foreign Affairs, 18-35.

Parliamentary Centre. (2009). The Public Accounts Committee of the Parliament of Ghana. Canada/Ghana: Parliamentary Centre.

Parliament of Ghana. (2018). Public Accounts Committee. Retrieved from https:// www.parliament.gh/committees?com=27

Riggins, S. H. (Ed.). (1997). The language and politics of exclusion: Others in discourse. Communication and Human Values, 24,

Said, E. W. (1978). Orientalism: western representations of the orient. London, UK: Routledge.

Sarfo, E. (2016). Questioning and debating in UK and Ghanaian parliamentary discourse. (PhD Thesis). University of Leeds.

Sarfo-Kantankah, K.S. (2018). Corruption is a big issue: A corpus-assisted study of the discursive construction of corruption in Ghanaian parliamentary discourse. Legon Journal of the Humanities, 29(1), 226-258.

Silbey, S.S. (1989). A sociological interpretation of the relationship between law and society. In Richard J. Neuhaus, (Ed.), Law and the ordering of our life together. (1-27) Grand Rapids, Michigan: William B. Eerdmans Publishing Company.

Sosoni, V. (2017). The rhetoric of othering in the Greek parliament: representation of the Troika and the self/other dichotomy. Lodz Papers in Pragmatics, 11(2), 271-286. DOI: https://doi.org/10.1515/1pp-2015-0014

Sparling, R. (2016). Motesquieu on corruption: Civic purity in a post-republican world. In Geoffrey C. Kellow and Neven Leddy, (Eds.), On Civic Republicanism (157-184)

Toronto: University of Toronto Press,. Retrieved from: http:/www.jstor.org/ stable/10.3138/j.ctt1kk65xt.12

Spivak, G. C. (1985). Can the subaltern speak? Wedge, 7(8), 120-130.

Staszak, J.-F. (2008). Other/otherness. In R. Kitchin \& N. Thrift (Eds.), International encyclopedia of human geography, 43-47. 
Sarfo-Kantankah, K.S. \& Arko, J./Compared to them, we are angels: Parliament, othering and the fight against corruption in Ghana

Stemler, S. (2001). An overview of content analysis. Practical Assessment, Research \& Evaluation, 7(17). Retrieved from http://PAREonline.net/getvn. asp? $\mathrm{v}=7 \& \mathrm{n}=17$

Thompson, G. and Hunston S. (1999). Evaluation: An introduction. In: Hunston, $\mathrm{S}$ and Thompson, G. (Eds.) Evaluation in text: Authorial stance and the construction of discourse. Oxford: Oxford University Press, pp.1-27.

UNODC (2003). The United Nations convention against corruption. Retrieved from http://www.unodc.org/documents/treaties/UNCAC/ Publications/ Convention/08- 50026_E.pdf

UNODC (2018a). Strengthening global integrity and ethics: UNODC finalizes series of new university modules under the education for justice initiative. Retrieved from http:/www.unodc.org/dohadeclaration/en/news/2018/05/ strengthening-global- integrity-and-ethics_unodc-finalizes-series-of-newuniversity-modules-under-the- education-for-justice-initiative.html

UNODC (2018b). UNODC's action against corruption and economic crime. Retrieved from http://www.unodc.org/unodc/en/corruption/thematic-areas. html

Van Der Valk, I. (2003). Right-Wing parliamentary discourse on immigration in France. Discourse Society, 14, 309-348.

Van Dijk, T.A. 1997. Political discourse and racism: describing others in Western parliaments. In S.H. Riggins (Ed.), The language and politics of exclusion (pp. 31-64). Thousand Oaks, CA: Sage Publications, 1997.

Van Dijk, T.A. (2000a). On the analysis of parliamentary debates on immigration. In M. Reisigl \& R. Wodak (Eds.), The semiotics of racism: approaches to critical discourse analysis (pp. 85-103). Vienna: Passagen Verlag.

Van Dijk, T. A. (2000b). Ideologies, racism, discourse: Debates on immigration and ethnic issues. Comparative Perspectives on Racism, 91-116.

Van Dijk, T.A. (2011). Discourse and ideology. In T.A. van Dijk (Ed.), Discourse studies: a multidisciplinary introduction (pp. 379-407). London: Sage.

Van Houtum, H. \& van Naerssen, T. (2001). Bordering, ordering and othering. Tijdschrift voor Economische en Sociale Georgafie, 93(2), 125-136.

Van Leeuwen, T. (2008). Discourse and practice: New tools for critical discourse analysis. Oxford: Oxford University Press.

Weber, R.P. 1990. Basic content analysis ( $2^{\text {nd }}$ ed.). London: Sage Publications. 
